\title{
Protective Effect of Carnosine on Hepatic Ischemia-Reperfusion Injury in Rats
}

\author{
Karaciğer İskemisinde Karnozinin Koruyucu Etkisi
}

\author{
${ }^{1}$ Sabiha Sahin, ${ }^{2}$ Ufuk Uylas, ${ }^{3}$ Varol Sahinturk, ${ }^{4}$ Ozkan Alatas \\ ${ }^{1}$ Department of Pediatrics, Faculty of Medicine, Eskisehir Osmangazi University, Eskisehir, Turkey \\ ${ }^{2}$ Department of General Surgery, Faculty of Medicine, Eskisehir Osmangazi University, \\ Eskisehir, Turkey \\ ${ }^{3}$ Department of Histology and Embryology, Faculty of Medicine, Eskisehir Osmangazi University, \\ Eskisehir, Turkey \\ ${ }^{4}$ Department of Medical Biochemistry, Faculty of Medicine, Eskisehir Osmangazi University, \\ Eskisehir, Turkey
}

\begin{abstract}
This study investigated the antioxidant effects of carnosine (CAR) in rats exposed to hepatic ischemia-reperfusion (I/R) injury using biochemical and histopathological evaluation. Twenty-four Sprague-Dawley male rats weighing 200-250 g were used to investigate the antioxidant effects of carnosine on the liver. Rats were randomly divided into the following groups: sham (control) group (G1), hepatic I/R group (G2), and hepatic I/R treated with $100 \mathrm{mg} / \mathrm{kg}$ CAR group (G3). Rats in the control group underwent only laparotomy and catheterisation. Rats in the other groups received $2 \mathrm{~h}$ of reperfusion following $1 \mathrm{~h}$ of hepatic ischemia by hepatic artery clamping after laparotomy. Rats in the treatment group received an intraperitoneal (i.p.) injection of $100 \mathrm{mg} / \mathrm{kg}$ CAR $60 \mathrm{~min}$ before hepatic artery clamping. All rats were monitored for $48 \mathrm{~h}$. Then, they were sacrificed and blood samples were obtained for determination of aspartate transaminase (AST), alanine transaminase (ALT), and liver tissue samples were taken for malondialdehyde (MDA), glutathione (GSH) and catalase (CAT) levels, and for the histopathologic examination as well. Serum AST, ALT and tissue MDA levels were significantly decreased and GSH and CAT levels were significantly higher in the CARtreated group compared to the non-treated group exposed to only I/R injury. Histopathological damage was significantly less in rats which received carnosine than that of non-treated group. We concluded that $100 \mathrm{mg} / \mathrm{kg}$ CAR may be effective in preventing the oxidative damage in liver tissue due to $\mathrm{I} / \mathrm{R}$ injury.
\end{abstract}

Keywords: liver, ischemia-reperfusion, carnosine, oxidative stress

Özet: Bu çalışmada, biyokimyasal ve histopatolojik değerlendirme kullanılarak karaciğer iskemisi-reperfüzyon (İ / R) hasarına maruz kalan sıçanlarda karnosinin (CAR) antioksidan etkileri araştırıldı. Karnosinin karaciğer üzerindeki antioksidan etkilerini araştırmak için 200-250 gr ağırlığındaki yirmi dört Sprague-Dawley erkek sıçan kullanıldı. Sıçanlar rastgele aşağıdaki gruplara ayrıldı: Kontrol grubu (G1), hepatik I / R grubu (G2) ve $100 \mathrm{mg} / \mathrm{kg}$ CAR ile tedavi edilen hepatik I / R grubu (G3). Kontrol grubundaki sıçanlara sadece laparotomi ve kateterizasyon uygulandı. Diğer gruplardaki ler, laparotomi sonrası hepatik arter klemplenmesi ile 1 saat hepatik iskemi sonrasında 2 saat reperfüzyona maruz bırakıldı. Tedavi grubundaki farelere, hepatik arter klemplenmeden 60 dakika önce $100 \mathrm{mg} / \mathrm{kg}$ CAR 60 dakika intraperitoneal enjeksiyon olarak yapıldı. Tüm sıçanlar 48 saat izlendi. Daha sonra sacrifiye edilip aspartat transaminaz (AST), alanin transaminaz (ALT) tayini için kan örnekleri alındı ve malondialdehit (MDA), glutatyon (GSH) ve katalaz (CAT) seviyelerin ölçmek için ve histopatolojik incelemeiçin karaciğer doku örnekleri alındı. Tedavi grubunda Serum AST, ALT ve doku MDA düzeyleri anlamlı olarak azaldı ve GSH ve CAT düzeyleri CAR ile tedavi edilen grupta, sadece I / R yaralanmasına maruz kalan tedavi edilmeyen grupla karşılaştıııldı̆̆ında anlamlı olarak daha yüksekti. Karnosin alan sıçanlarda histopatolojik hasar, tedavi edilmeyen gruba göre anlamlı derecede azdı. Bu çalışma sonucunda $100 \mathrm{mg} / \mathrm{kg}$ CAR'ın, İ / R hasarı nedeniyle karaciğer dokusunda oksidatif hasarı önlemede etkili olabileceği sonucuna vardık.

Anahtar Kelimeler: karaciğer, iskemi-reperfüzyon, karnosin, oksidatif stres

ORCID ID of the authors: S.Ş. 0000-0003-0759-4158; U.U. 0000-0003-4195-5498; V.Ș. 0000-0003-2317-3644; Ö.A. 0000-0001-8430-5298

Received 12.11 .2018

Accepted 04.03.2019

Online published 04.03 .2019

Correspondence: Sabiha ŞAHIN- Department of Pediatrics, Faculty of Medicine, Eskisehir Osmangazi University, Eskisehir, Turkey e-mail- $\underline{\text { sabiha.sahin@mynet.com }}$

Cite this article as:

Sahin S, Uylas U ,Sahinturk V, Alatas O. Protective Effect of Carnosine on Hepatic Ischemia-Reperfusion Injury in Rats, Osmangazi Journal of Medicine, 2020;42(3):269- $276 \quad$ Doi: 10.20515/otd. 481714 


\section{Introduction}

Ischemia is defined as an insufficient blood supply due to arterial occlusion of any cause. Cell death and organ failure are the most frequent results of ischemia (1). Interrupted blood flow and decreased transport of oxygen activate anaerobic metabolism.

Carden et al. showed that deposition of lactic acid and toxic metabolites in the tissue contributes to the cellular injury. Reperfusion is the restoration of blood flow to the ischemic tissue (1). Teoh et al. reported that reperfusion of ischemic tissue was essential for tissue survival, but resulted in reperfusion injury (2). They demonstrated the importance of oxygen-derived free radicals following restoration of oxygenated blood flow into the tissue in ischemia/reperfusion (I/R) damage.

Numerous mechanisms of I/R damage have been suggested. Oxidative stress is caused by excess free oxygen radicals resulting from altered mitochondrial oxidative phosphorylation, decreased adenosine triphosphate (ATP) and increased intracellular $\mathrm{Ca}^{+2}$ levels, and activation of proteases and phosphatases (3). The pro-/antioxidant balance is crucial for health. Various antioxidant mechanisms prevent generation of free radicals to protect cells from their harmful effects (4-11).

Free oxygen radicals cannot be measured directly because of their instability and short half-life. Malondialdehyde (MDA), the end product of lipoperoxidation, can be used to determine the effect of free radicals on membrane lipids (12). Cells have a variety of defense mechanisms to improve the harmful effects of reactive oxygen species (ROS). Superoxide dismutase (SOD) catalyses the conversion of two superoxide anions into a molecule of hydrogen peroxide $\left(\mathrm{H}_{2} \mathrm{O}_{2}\right)$ and oxygen $\left(\mathrm{O}_{2}\right)$. Glutathione peroxidase is a group of enzymes containing selenium, which also catalyses the degradation of $\mathrm{H}_{2} \mathrm{O}_{2}$, as well as organic peroxides to alcohols. In previous studies of complete or incomplete ischemia, MDA, glutathione (GSH), and catalase (CAT) were used as markers of cell wall disintegration (13).

Carnosine (beta-alanyl-L-histidine) (CAR) is a biologically active dipeptide. Natural CAR derivatives include CAR-related dipeptides
(CRCs) or aminoacyl-histidine dipeptides, which comprise homocarnosine (gamma-aminobutyrileL-histidine), anserin (beta-alanyl-L-1methylhistidine), balain, ophidine, and betaalanyl-L-histidine. CAR scavenges free radicals and aldehydes and suppresses oxidative changes in proteins. CAR is present at high concentrations in tissues including the brain, bone, and cardiac muscle, and at lower levels in the lens, stomach, and kidney. The protective effect of CAR against $\mathrm{I} / \mathrm{R}$ liver injury in rats has been evaluated previously. However, there is no study examining the effect of low-dose CAR $(100 \mathrm{mg} / \mathrm{kg})$ on hepatic I/R damage by hepatic artery clamping in rats in the literature. Therefore, we investigated the protective effects of low-dose CAR on hepatic I/R damage in rats.

\section{Materials and Methods}

This study was performed in Eskisehir Osmangazi University, Faculty of Medicine (ESOGU), Medical and Surgical Investigation Laboratory, and was approved by the Local Ethics Committee (May 8, 2014, no. 399). Study animals were obtained from Eskisehir Osmangazi University, Faculty of Medicine, Medical and Surgical Investigation Laboratory (TICAM).

Twenty-four Sprague-Dawley male rats weighing 200-250 g were randomly divided into three groups ( $\mathrm{n}=8$ each). Group 1 (control) consisted of rats that underwent sham operation/laparotomy and were given saline. Group 2 consisted of rats that received $1 \mathrm{~h}$ of total hepatic ischemia $+2 \mathrm{~h}$ of reperfusion. Group 3 consisted of rats that received intraperitoneal (i.p.) injection of 100 $\mathrm{mg} / \mathrm{kg} \mathrm{CAR}+1 \mathrm{~h}$ of total hepatic ischemia $+2 \mathrm{~h}$ of reperfusion. CAR pretreatment was performed $60 \mathrm{~min}$ before hepatic clamping (6-7).

\section{Surgical Procedure}

Rats were fasted overnight (with access to water) and underwent abdominal laparotomy under general anaesthesia induced by i.p. injection of $50 \mathrm{mg} / \mathrm{kg}$ ketamine (Ketalar; Parke-Dawis, Eczacibaş1, Istanbul, Turkey) and $10 \mathrm{mg} / \mathrm{kg}$ xylazine hydrochloride (Rompun; Bayer AG, Leverkusen, Deutschland). During the operation, spontaneous breathing was provided. A heat lamp was used to maintain a body temperature of $\sim 37^{\circ} \mathrm{C}$. After shaving the abdomen, the surgical area was wiped twice with $10 \%$ povidone-iodine, and the operation was performed in an aseptic 
manner. The hepatic artery was located by median laparotomy. The hepatic arteries, portal vein, and bile tract were clamped to induce $\mathrm{I} / \mathrm{R}$ injury. $100 \mathrm{mg}$ CAR (i.p.) was administered 60 min before clamping. At the end of the experiment, the rats were anaesthetised with xylazine hydrochloride and ketamine and sacrificed after $24 \mathrm{~h}$. Blood samples were collected into biochemical tubes by heart puncture. Serum samples were used to determine the levels of ALT and ALP, and liver tissue samples were taken for MDA, GSH and catalase (CAT) levels, and for the histopathologic examination as well.

\section{Biochemical Assessment}

Blood samples were collected into biochemical tubes by heart puncture and centrifuged for 10 min at $3500 \mathrm{rpm}(4000 \mathrm{~g})$ to obtain a clear serum and stored at $-80^{\circ} \mathrm{C}$. All assessments were performed at Eskisehir Osmangazi University Medical Faculty, Biochemistry Department. AST and ALT levels were measured using commercial assay kits. The liver tissue was excised immediately and washed with ice-cold saline. A portion of liver tissue was homogenized with 0.1 $\mathrm{M}$ Tris $\mathrm{HCl}$ at $\mathrm{pH}$ 7.4, and the homogenate was used to determine lipid peroxidation (MDA, CAT, GSH).

Serum ALT and AST levels were measured using a modular autoanalyzer (Roche, Mannheim, Germany). Serum ALT and AST activities were expressed by units per liter (U/L) (9).

Tissue samples were weighed using a microbalance and homogenized in $0.15 \mathrm{M} \mathrm{KCL}$ at a 1:10 ratio. Homogenates were centrifuged at $4000 \mathrm{rpm}$ at $4^{\circ} \mathrm{C}$, and the supernatants were used for MDA measurements. For each $0.4 \mathrm{~mL}$ of supernatant, $1.5 \mathrm{~mL}$ TBA $(0.08 \%$; pH 5.5), 1.5 $\mathrm{mL}$ acetic acid (20\%; $\mathrm{pH} 3.5)$ and $0.2 \mathrm{~mL}$ sodium dodecyl sulfate were added. MDA standards were diluted fresh from stock MDA standards. Mixed samples and standards were boiled at $100^{\circ} \mathrm{C}$ for 1 $\mathrm{h}$, cooled using cold water, and $5 \mathrm{~mL}$ n-butanol was added. The tubes were centrifuged at 4,000 rpm for 10 min. Plasma MDA levels were also measured using the procedure described above (10).

CAT levels were determined using a Cayman enzyme-linked immunosorbent assay (ELISA) kit Rat Catalase (CAT) ELISA kit; MGC138422.
GSH was measured according to the method of Schroeter et al. (14). Briefly, after washing with cold $\left(4^{\circ} \mathrm{C}\right)$ isotonic $0.9 \% \mathrm{NaCl}$, liver tissue samples were air-dried, and $100 \mathrm{mg}$ of each were homogenized in $1 \%$ picric acid. Absorbance at $412 \mathrm{~nm}$ was determined, and the GSH concentration was calculated $(\mathrm{nmol} / \mathrm{mL})$ using a calibration curve; the GSH concentration ( $\mu \mathrm{mol})$ per gram tissue was also calculated.

\section{Histopathological Assessment}

The liver was fixed in $10 \%$ neutral formalin for histological investigations. Four micrometerthick paraffin sections were taken from each liver sample and stained with hematoxylin and eosin (H\&E). Samples were examined by light microscopy by using Spot Advanced Software (V.3.2.4; Diagnostic Instruments, Sterling Heights, USA). Sections were digitally photographed using a Spot insight colour 3.2.0 diagnostic camera. All assessments were performed at Eskisehir Osmangazi University Medical Faculty, Department of Histology and Embryology.

Histopathological assessment included semiquantitative scoring of polymorphonuclear leukocyte (PMNL) infiltration, congestion in hepatic vessels, haemorrhage, and degeneration of hepatocytes (hydropic degeneration, vacuolar degeneration, and necrosis). Histological findings were rated as absent $(-)$, mild $(+)$, moderate $(++)$ or severe $(+++)(12)$.

\section{Statistical Analysis}

Statistical analyses were performed using IBM SPSS 20.0 software. The Shapiro-Wilk test was used to assess the normality of the distribution of values. Non-parametric comparisons were performed by the Kruskal-Wallis test. The significance level was set at $p<0.05$. The data were expressed as the mean \pm SD.

\section{Results}

Figure 1 shows the changes in hepatic biochemical parameters following $\mathrm{I} / \mathrm{R}$ injury in rats treated or untreated with CAR. AST and ALT levels were significantly lower in Group 3 (treatment group) than in Group 2 (I/R only group) ( $<<0.001)$. MDA levels were significantly lower in Group 3 than in Group 2 ( $\mathrm{p}<0.05)$. GSH and CAT levels were significantly higher in Group 3 (treatment group) than in Group 2 
$(\mathrm{p}<0.05)$. There was no statistically significant difference between Group 1 and Group 3.Our induced by I/R was significantly suppressed by findings showed that hepatic lipid peroxidation

pretreatment with CAR. ( Figure 1 ,Table 1)

Table 1. Changes in liver biochemical parameters following ischemia/reperfusion (I/R) injury in rats treated and untreated with carnosine (CAR)

\begin{tabular}{|c|c|c|c|c|c|}
\hline & Groups & Mean & $\mathrm{SD} \pm$ & $\mathbf{F}$ & p \\
\hline \multirow[t]{3}{*}{$\mathrm{AST}^{* *}$} & G1 Control & 545,75 & 235,33 & 8,16 & 0,000 \\
\hline & G2 $\quad \mathrm{I} / \mathrm{R}$ & 1301,62 & 273,61 & & \\
\hline & G3 I/R + CAR & 702,75 & 538,98 & & \\
\hline \multirow[t]{3}{*}{$\mathrm{ALT}^{* *}$} & G1 Control & 176,50 & 144,90 & 4,33 & 0,000 \\
\hline & G2 I/R & 1362,83 & 156,50 & & \\
\hline & G3 I/R+CAR & 262,83 & 144,19 & & \\
\hline \multirow{3}{*}{$\begin{array}{l}\text { MDA* Malondialdehyde } \\
\text { (nmol/g tissue) }\end{array}$} & G1 Control & 21,05 & 6,53 & 4,82 & 0,04 \\
\hline & G2 I/R & 38,76 & 14,20 & & \\
\hline & G3 I/R+CAR & 22,28 & 16,04 & & \\
\hline \multirow{3}{*}{$\begin{array}{c}\text { GSH* : Glutathione } \\
\text { peroxidase (U/g tissue) }\end{array}$} & G1 Control & 0,93 & 0,29 & \multirow[t]{3}{*}{0.24} & \multirow[t]{3}{*}{0.03} \\
\hline & G2 I/R & 0,46 & 0,59 & & \\
\hline & G3 I/R+CAR & 0,88 & 0,22 & & \\
\hline \multirow{3}{*}{$\begin{array}{l}\text { CATALASE * } \\
\text { ( U/mg tissue ) }\end{array}$} & G1 Control & 328,05 & 148,38 & \multirow[t]{3}{*}{6,62} & \multirow[t]{3}{*}{0,006} \\
\hline & $\mathrm{G} 2 \quad \mathrm{I} / \mathrm{R}$ & 630,34 & 257,38 & & \\
\hline & G3 I/R+CAR & 491,58 & 229,65 & & \\
\hline
\end{tabular}

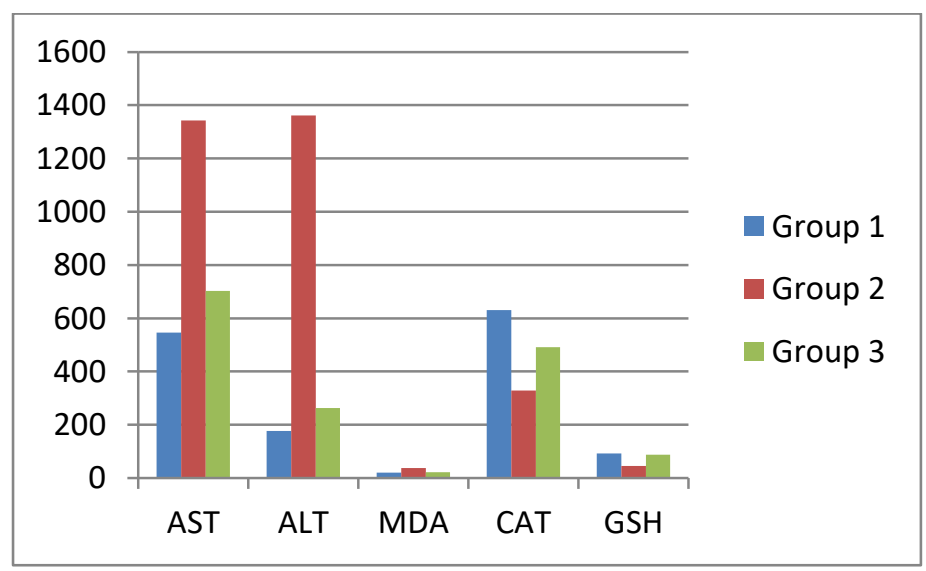

Figure 1. Biochemical evaluation findings of all groups at the end of the study.

AST, ALT, MDA, GSH and CAT levels (Group 1; Control, Group 2; hepatic I/R group, Group 3; hepatic I/R group treated with 100 $m g / k g(A R)$. A highly significant difference was determined on AST,ALT levels between G3 treatment group and G2 I/R group. $(p<0.001$.) (***)A significant difference was determined on MDA levels between G3 treatment group and G2 I/R group. $(P<0.05)^{*} A$ significant difference was determined on GSH and catalase levels between G3 treatment group and G2 I/R group. ( $P<0.05)^{*}$ (A significant difference was determined on GSH levels between G3 treatment group and G2 I/R group. $(P<0.05)^{*}$. * (Group 1; Control, Group 2; hepatic I/R group, Group 3; hepatic I/R group treated with $100 \mathrm{mg} / \mathrm{kg}$ CAR) (*p<0.05, ***p<0.001.) 


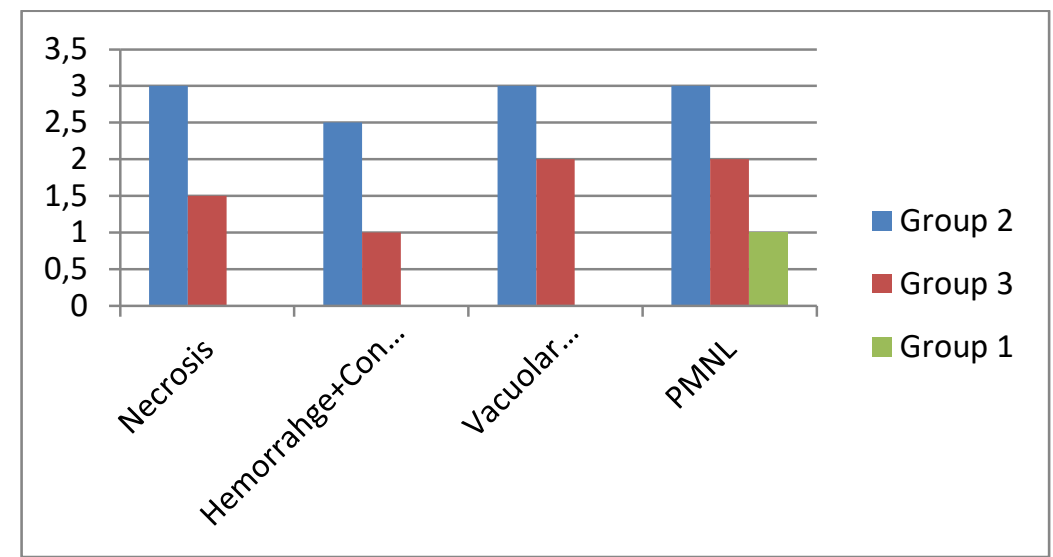

Figure 2. Histological evaluation findings of all groups at the end of the study.

\begin{abstract}
Markedly decreased necrosis, hemorrage,vacuolar degeneration and sinusoidal dilatation, congestion, and cellular inflammation in the portal region were observed in liver tissue specimens of rats treated with carnosine Group 3, especially when compared to Group 2 significantly. (Group 1; Control, Group 2; hepatic I/R group, Group 3; hepatic I/R group treated with $100 \mathrm{mg} / \mathrm{kg}$ CAR). ${ }^{*} p<0.05$, $\left.{ }^{* * *} p<0.001\right)$
\end{abstract}

In group 1 , hepatocytes were of normal shape. (Figure 3 A). In group 2, hepatocyte nuclei lost their normal shape and staining characteristics and became small, dense, and irregular. Sinusoids were enlarged, and the loop array of hepatocytes degenerated. Vacuolation and balloon degeneration, haemorrhage, congestion, necrosis, and PMNL infiltration were remarkable in Group 2. (Figure 3 B ) In Group 3 (CAR-treated I/R group), hepatocyte nuclei had, in part, lost their normal shape and staining characteristics and became relatively small, dense, and irregular. Hepatocyte nuclei and cytoplasm maintained their shapes and staining characteristics. Few sinusoidal congestion sites were present and histological organisation was protected (Figure $3 \mathrm{C})$.

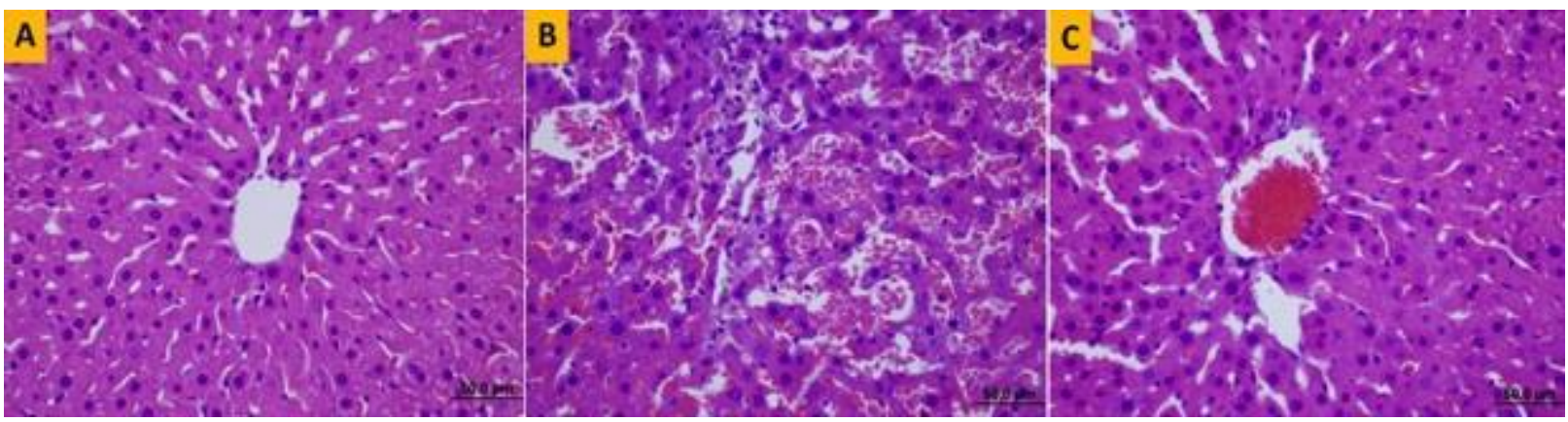

Figure 3. Light microscopic examination $(H \& E, \times 400)$. A) Control group. B) I/R injury group (Group 2) showing ballooning of hepatocytes with cytoplasmic vacuolation and loss of definition of liver plates, focal spotty necrosis of individual cells surrounded by relatively intact hepatocytes, Kupffer cell hyperplasia, and more or less preserved hepatic architecture without ballooning. C) CAR-treated I/R group (Group 3). Pre-ischemic treatment with CAR markedly attenuated the I/R-induced histopathological changes in rats.

\title{
4. Discussion
}

We evaluated the effect of CAR on histopathological changes in the liver tissue due to hepatic I/R induced by clamping of hepatic arteries, the portal vein, and biliary tract. Free radicals damage cell membranes by lipid peroxidation and trigger the production of inflammatory mediators, which leads to tissue damage (12-16). Fouad et al. showed that a single i.p. dose of CAR $(250 \mathrm{mg} / \mathrm{kg})$ administered 30 min before the ischemic episode significantly attenuated the deterioration in biochemical parameters caused by I/R-induced liver injury 
(6). Also, in the same study, light and electron microscopic examination of untreated rats revealed severe hepatic damage, such as cytoplasmic vacuolation and necrotic and apoptotic cell death, which was markedly ameliorated by CAR pretreatment. These results suggest that CAR has a potential as a prophylactic agent to protect the liver against hypoxia-reoxygenation damage. Artun et al. (17) reported that MDA levels were lower in rats pretreated with CAR compared to those exposed to oxidative stress. Kalaz et al. (18) investigated the effects of CAR and taurine on hepatic oxidative stress induced by D-galactose. They reported that when CAR and taurine were given individually or concomitantly at $250 \mathrm{mg} / \mathrm{kg} /$ day i.p. for five days/week, lipid destruction and histopathologic changes were improved. Kuloglu et al. (19) demonstrated protective effects of CAR on carbon tetrachloride-induced liver damage in rats. Serum ALT and AST levels, liver MDA levels, HSP-70 expression, and steatosis were increased following treatment with carbon tetrachloride. Administration of $200 \mathrm{mg} / \mathrm{kg} / \mathrm{day}$ CAR for five days ameliorated hepatic damage, and they reported that HSP-70 might have mediated this effect. Sahin et al. (20) reported that $100 \mathrm{mg} / \mathrm{kg}$ CAR reduced MDA levels in rats with oxidative stress induced by septic shock. We measured MDA levels to assess oxidative stress and found that $100 \mathrm{mg} / \mathrm{kg}$ CAR treatment significantly decreased the MDA levels in the liver tissue exposed to I/R injury.

CAR reportedly exhibits antioxidant activity, similar to CAT, glutathione peroxidase, and glutathione reductase. Several previous studies of complete or incomplete ischemia used GSH as a marker of oxidative stress. Yan et al. (21) showed that CAR significantly ameliorated the reduction in GSH levels in rats with oxidative damage due to acetaminophen-induced hepatic I/R injury. Fouad et al. (6) reported that CAR treatment reduces the decrease in GSH levels in in rats with liver ischemia/reperfusion injury. In an oxidative stress model, Kalaz et al. (18) reported that CAR reduced lipid destruction, and improved histopathologic parameters. In this study, the reduction in GSH levels caused by I/R injury was ameliorated by CAR treatment, which was likely to be due to its antioxidant activity $(21,22)$.

CAT is also used as a marker of oxidative stress. In a study by Yan et al. (21), the CAT level was significantly increased in the CAR-treated I/R group in the liver tissue compared to the I/R only group. CAT is an indicator of reoxygenation damage, and reduced CAT levels suggest freeradical-induced damage after reperfusion. In our study, CAT levels were significantly higher in rats treated with $100 \mathrm{mg} / \mathrm{kg}$ CAR than in rats exposed to I/R only.

Measurement of AST and ALT activity is typically performed to assess hepatic damage. Fouad et al. (6) reported increased ALT and AST levels after hepatic I/R damage and suggested that these increases occur as a result of free radical damage, and could be prevented by CAR. Baykara et al. (22) reported increased ALT and AST levels in rats with hepatic I/R, and that CAR and taurine treatment decreased these levels. In a study of diethylnitrosamine-induced oxidative stress, Basaran et al. (23) reported significantly increased ALT levels in rats exposed to oxidative stress and significantly decreased ALT levels in rats treated with CAR. Kuloglu et al. (19) reported that rats that received carbon tetrachloride exhibited significantly higher ALT and AST levels than rats administered carbon tetrachloride and CAR. Similarly, Tokyol et al. (24) reported increased ALT and AST levels after hepatic I/R, which suggested free-radical-induced hepatic tissue damage; and these increases were ameliorated by CAR. In our study, the increases in AST and ALT levels caused by I/R damage were significantly ameliorated by CAR pretreatment. Therefore, hepatic tissue damage was reduced by the antioxidant activity of CAR.

In previous studies, CAR improved the histopathological changes in the liver caused by I/R. Baykara et al. (22) reported that CAR ameliorated the PMNL infiltration, hepatocyte necrosis, and sinusoidal enlargement in the liver tissue caused by I/R. Basaran et al. (23) demonstrated that CAR and melatonin significantly improved the sinusoidal congestion, cytoplasmic vacuolization, hepatocellular necrosis and neutrophil infiltration caused by hepatic I/R. Kuloglu et al. (19) reported that CAR ameliorated the steatosis and histopathological changes caused by carbon tetrachloride-induced oxidative damage. In our study, inflammation, sinusoidal enlargement and congestion, and extensive areas of hepatocyte necrosis were evident in the $\mathrm{I} / \mathrm{R}$ group. However, necrosis, haemorrhage, vacuolar degeneration, sinusoidal dilatation, and cellular inflammation in the portal 
region were significantly reduced in rats treated with CAR.

\section{Conclusion}

$\mathrm{I} / \mathrm{R}$ damage is frequently seen in clinical practice. Hepatic transplantation, shock, hypoxia, myocardial infarction, trauma and trauma surgery, orthopaedic surgery, cardiovascular surgery, transplantation surgery, sepsis, burns, pancreatitis, and cerebrovascular diseases may result in $\mathrm{I} / \mathrm{R}$ damage. The effect of a natural antioxidant, CAR, on I/R liver injury in rats was evaluated in this study. Therefore, based on our results and previous reports $(25,26)$, we conclude that low doses of CAR have the potential for prevention of hepatic I/R damage after hepatic transplantation, shock, hypoxia, trauma, and ischemic events.

\section{Acknowledgements}

No financial support was received. This study was performed in Eskisehir Osmangazi University Faculty of Medicine (ESOGU), Medical and Surgical Investigation Laboratory, and was approved by the local Ethics Committee (8 May 2014, no. 399).

\section{REFERENCES}

1. 1.Carden DL, Granger DN. Pathophysiology of ischemia-reperfusion injury. Pathol. 2000;190:255-66.

2. Teoh NC, Farrell GC. Hepatic ischemiareperfusion injury: pathogenic mechanisms and basis for hepatoprotection. $J$ Gastroenterol Hepatol. 2003;18:891-902

3. Valko M, Leibfritz D, Moncol J, Cronin MTD, Mazur M, Telser J. Free radicals and antioxidants in normal physiological functions and human disease. Int J Biochem Cell Biol. 2007;39(1):44-84.

4. Golubović S, Stanković I, Ristić L, Cosić V, Dordević I, Radović M. Antioxidant enzymes and lipid peroxidation products in patients with pulmonary tuberculosis. Med Pregl. 2010;63:450-3

5. Abdel-Gaber SA,Ibrahim MA,Amin EF,Ibrahim SA,Mohammed RK,Abdelrahman AM. Effect of selective versus non-selective cyclooxygenase inhibitors on ischemiareperfusion-induced hepatic injury in rats. Life Sci. 2015;134:42-8.

6. Fouad AA,El-Rehany MA,Maghraby HK. The hepatoprotective effect of carnosine against ischemia/reperfusion liver injury in rats. Eur $J$ Pharmacol. 2007;572:61-8.

7. Yamashita S, Sato M, Matsumoto $T$. Mechanisms of carnosine-induced activation of neuronal cells. Biosci Biotechnol Biochem. 2017;11:1-6.

8. Sahin S, Burukoglu Donmez D. Effects of carnosine (Beta-Alanyl-L-Histidine) in an experimental rat model of acute kidney injury due to septic shock. Med Sci Monit. 2018;24:305-16.

9. Jamshidzadeh A, Heidari R, Latifpour Z Carnosine ameliorates liver fibrosis and hyperammonemia in cirrhotic rats. Clin Res Hepatol Gastroenterol. 2017;41:424-34.

10. Qi B, Wang J, Ma YB, Wu SG. Effect of dietary $\beta$-alanine supplementation on growth performance, meat quality, carnosine content, and gene expression of carnosine-related

enzymes in broilers. Poult Sci. 2018;97:122028.

11. Nakagawa K, Kawagoe M, Yoshimura M, Arata H, Minamikawa T, Nakamura M. Differential effects of flavonoid carnosine on oxidative damages induced by hydrophilic and lipophilic radical generator in hepatic lysosomal fractions of mice. J Health Science. 2000;46:509-12.

12. Peralta C, Bartrons R, Serafin A, Blazquez C, Guzman M, Prats N. Adenosine monophosphate-activated protein kinase mediates the protective effects of ischemic preconditioning on hepatic ischemiareperfusion injury in the rat. Hepatology. 2001;34:1164-73.

13. Aydın AF, Bingül İ, Küçükgergin $\mathrm{C}$, DoğanEkici I, Doğru Abbasoğlu S, Uysal M.Carnosine decreased oxidation and glycation products in serum and liver of highfat diet and low-dose streptozotocin-induced diabetic rats.Int J Exp Pathol. 2017;98:278-88.

14. Schroeter R, Lankisch PG, Lege L, Vogt W. Possible implication of glutathione reductase in haemolysis by the direct lytic factor of cobra venom (Naja naja). Naunyn Schmiedebergs Arch Pharmacol. 1972;275:203-11.

15. Yabe $\mathrm{Y}$, Kobayashi $\mathrm{N}$, Nishihashi $\mathrm{T}$, Takahashi R, Nishikawa M, Takakura Y. Prevention of neutrofil-mediated hepatic ischemia-reperfusion injury by superoxide dismutase and catalase derivatives. Journal of Pharmacology and Experimental Therapy. 2001;298:894-99.

16. Singh D, Chander V, Chopra K. The effect of carnosine, a bioflavonoid on ischemia/reperfusion induced renal injury in rats. Arch Med Res. 2008;39:714.

17. Artun BC, Küskü Kiraz $Z$, Güllüoğlu $M$, Cevikbaş U, Koçak Toker N, Uysal M. The effect of carnosine pretreatment on oxidative stress and hepatotoxicity in binge ethanol administered rats. Hum Exp Toxicol. 2010;29:659-65 
18. Kalaz EB, Çoban J, Aydın AF, Doğan Ekici I, Doğru Abbasoğlu S, Öztezcan S, Uysal M Carnosine and taurine treatments decreased oxidative stress and tissue damage induced by D-galactose in rat liver. $J$ Physiol Biochem. 2014;70:15-25.

19. Kuloglu N, Sönmez MF. A biochemical and immunohistochemical study of the protective effects of carnosine for carbon tetrachloride induced liver injury in rats. Biotech Histochem. 2015;90:608-14.

20. Sahin S, Oter S, Burukoğlu D, Sutken E. The effects of carnosine in an experimental rat model of septic shock. Med Sci Monit Basic Res. 2013;19:54-61.

21. Yan SL, Wu ST, Yin MC, Chen HT, Chen HC. Protective effects from carnosine and histidine on acetaminophen-induced liver injury.J Food Sci. 2009;74:259-65.

22. Baykara B, Tekmen I, Pekcetin C, Ulukus C, Tuncel P, Sagol O, Ormen M, Ozogul C. The protective effects of carnosine and melatonin in ischemia-reperfusion injury in the rat liver. Acta Histochem. 2009;111:42-51.

23. Başaran Küçükgergin C, Bingül I, Tekkeşin MS, Olgaç V, Doğru Abbasoğlu S, Uysal M. Effects of carnosine, taurine, and betaine pretreatments on diethylnitrosamine-induced oxidative stress and tissue injury in rat liver. Toxicol Ind Health. 2016;32:1405-13.

24. Bingül İ, Yılmaz Z, Aydın AF, Çoban J, Doğru-Abbasoğlu S, Uysal M1.Antiglycation and anti-oxidant efficiency of carnosine in the plasma and liver of aged rats.Geriatr Gerontol Int. 2017;17:2610-14

25. Welker AF, Moreira DC, Hermes-Lima M. Roles of catalase and glutathione peroxidase in the tolerance of a pulmonate gastropod to anoxia and reoxygenation. J Comp Physiol B. 2016; 186: 553-68.

26. Prokopieva VD, Yarygina EG, Bokhan NA, Ivanova SA Use of Carnosine for Oxidative Stress Reduction in Different Pathologies.Oxid Med Cell Longev. 2016; 2016: 2939087. 